\title{
Acts of Meaning: The Legitimization of New Ventures
}

\author{
Al S. Lovvorn, Ph.D. (Corresponding author) \\ Assistant Professor of Business Administration, Citadel School of Business Administration \\ The Citadel, 171 Moultrie Street, Charleston, SC 29409, USA \\ Tel: 843-953-4829Ｅ-mail: al.lovvorn@citadel.edu
}

Jiun-Shiu Chen, Ph.D.

Associate Professor of Business Administration

Box 92135 MSU, Burton Business Center 227, McNeese State University

Lake Charles, LA 70609, USA

Tel: 337-475-5531Ｅ-mail: jschen@mcneese.edu

Received: November 12, 2012

doi:10.5430/jms.v4n1p28

\author{
Accepted: January 14, $2013 \quad$ Online Published: February 15, 2013 \\ URL: http://dx.doi.org/10.5430/jms.v4n1p28
}

\begin{abstract}
Using the lens of institutional theory and the legitimization construct, we discuss how new ventures select an organizational structure, how new ventures obtain legitimacy for their organizational structure, and change institutional norms. We examine how institutional forces may influence the organizational structure of new ventures in both established and new fields and discuss how institutional theory may provide an explanation of the organizational structures available to new venture firms entering into established business fields. Additionally, institutional theory is evoked to better understand the process by which new ventures may establish an organizational structure where no institutionalized (legitimated) structure currently exists.
\end{abstract}

Keywords: Institutional theory, Legitimization, Isomorphism, New ventures, Organizational form

\section{Introduction}

New ventures, at their inception, face an immediate crossroads. They must select a form from a wide range of organizational design alternatives that not only allow them to achieve their goals but also allow them to access or acquire valuable and necessary resources from the external environment. Thus, the selection of the organization's form is critical in order to garner legitimacy and sustain viability. Any structure selected may either constrain or strengthen a new venture's ability to access and exploit such resources (Scott, 1987; Selznick, 1949). Institutional theory and, in particular, its legitimization construct may provide insight into how new ventures select one organizational form over another. Thus, two important questions must be answered: How do new ventures select their organizational forms in an effort to maximize access to life sustaining resources, and, for those new ventures blazing entirely new market paths, how does their nascent, constructed structure evoke an acceptance of legitimacy from the broader, traditional market? New ventures do not just appear; rather they are formed to exploit opportunities, whether it is a discovered opportunity or the creation of an opportunity, entrepreneurs seek to exploit competitive imperfections in the market (Alvarez and Barney, 2007). Yet new ventures in their formal structure as a firm often start long before they are officially incorporated, and indeed many of the interesting internal processes that result in an established organizational form occur before incorporation. The formation and exploitation of opportunities thus leads to the formation of organizations that are created by the entrepreneur to take advantage of the perceived opportunity. Using opportunity formation as our starting point, we attempt to offer insight into when do new ventures need forms that follow the current institutional form's rules, governance, and structures and when do these new ventures need forms that are not imbedded in current institutions.

Entrepreneurs creating new ventures rarely are able to see "the end from the beginning" (Alvarez and Barney, 2007: 15). The process of creating a new venture is enacted in an iterative process of action and reaction (Berger and Luckmann, 1967; Weick, 1979); thus, there is no end until the new venture creation has occurred. This enactment of a 
new venture, with the end not known at the beginning, may result in a traditional (or standard) organizational structure to exploit the opportunity. Yet, some of these new ventures also may result in new forms-new structures that even disrupt or change established institutions as they seek to exploit the opportunity.

The research question we seek to explore is how institutional theory might provide insight into the organizational structure selected by new venture firms, and also how the new organizational form obtains legitimacy for that structure and thus changes acceptable institutional norms. Below we examine how institutional forces may influence the organizational structure of new ventures in both established and new fields. Our discussion will begin with a review of institutional theory literature; how the concept of organizational structure has developed and is used in this paper; and, a definition of our use of emerging field. From that point we will discuss how institutional theory may provide an explanation of the organizational structures available to new venture firms entering into established business fields. Following the assessment of new ventures in established fields, we use institutional theory to better understand the process by which new ventures may establish an organizational structure where no institutionalized (legitimated) structure currently exists.

\section{Institutional Theory}

Institutional theory emerged from a series of studies conducted by Selznick (1949) on the Tennessee Valley Authority; by Gouldner (1954) on a gypsum mine and plant; by Blau (1955), of a federal and state bureau; and, by Lipset, Trow, and Coleman (1956) of a typographic labor union organization. Selznick (1949) viewed institutionalization as a process of ensuring stability of organizational forms (Scott, 1987). The stability that institutionalism instilled endowed organizations with an intrinsic value, that is value beyond utility. In his view, as organizations "become the receptacles of group idealism; they are less readily expendable" (Selznick, 1957: 22). Thus, organizations were infused with value beyond their technical requirements for the tasks at hand (Selznick, 1957: 17), and they reflected the adaptive ability of the entity to manifest the characteristics and commitments of its constituent members as well as to the external stimuli of the environment (Scott, 1987). Selznick further argued that leaders enacted the organization's institutional values through their definition and defense of organizational missions (Selznick, 1957). Of particular importance to Selznick's version of institutional theory was the role of time and of history in imbuing legitimacy to the organization.

Berger and Luckmann (1967) articulated a different conceptualization of institutional theory with their explication of structure as a shared social reality created within social interactions. Temporality, as with Selznick, is the measure of institutionalism because institutionalism occurs only over the course of socially repeated events that are assigned essentially similar meanings by actors within the context of the event itself: "Institutionalization occurs whenever there is a reciprocal typification of habitualized actions by types of actors" (Berger and Luckmann, 1967: 54). Stated more succinctly, actors and their roles become typed - managers' issue orders while workers carry them out (Scott, 1987). Within the construct of structuration, Meyer and Rowan (1987) and Zucker (1983) articulate the view that social processes assume a rule-like status in thought and deed (Scott, 1987). Social processes become the shared definition of social reality - they evoke a conformity of common understanding to define rational, appropriate behaviors. In other words, this is "the way things are done" or "the way things are to be done" as scripts allow appropriate reaction to both expected and unexpected situations (Lord and Kernan, 1987).

A different, yet complementary, approach to contextualizing institutional theory was the argument that cultural elements are the loci of "rationalized and impersonal prescriptions that identify various social purposes" (Meyer and Rowan, 1977: 343). This shift in emphasis from social belief to social elements underlines the importance that other rationalized, social structures (e.g., professions, regulatory agencies, educational systems, etc.) have on the existence of an organization. As Hannan and Freeman (1989: 133) argued, "rarity of a form poses serious problems of legitimacy" and as a form becomes more common legitimacy increases. Conformity again is a factor because organizations mimic acceptable structures to gain reward through enhanced legitimacy of form - mimetic isomorphism (DiMaggio and Powell, 1983). Thus, a legitimate structure garners greater access to resources and survival capabilities.

A last broad contextual institutional theory schema views institutions as "distinct social spheres" (Scott, 1987). This view also relies on distal temporality to imbue the organization with legitimacy. Societal institutions can exist beyond the biological span of its members, and this temporal stability affords institutions with mechanisms for societal continuity. This point in an institution's existence also has been referred to as being "taken-for-granted"-the point at which there is a general understanding of what a business is and does (Aldrich and Fiol, 1994; Sorenson and Stuart, 2008; Suchman, 1995). Within this version of institutional theory, multiple, competing, and not always harmonious institutional forms exist and persist (Scott, 1987, 2001). The competition between institutions compels adaptive responses as societal needs, beliefs, and practices evolve. 
Institutional theory, in its myriad articulations, posits a consistent point - that there are forces that create homogeneity in organizational structure. Unfortunately, however, it has not been able to fully explicate how new organizational structures are introduced (i.e., resist the pressure to replicate and conform to previously legitimated structures) and eventually create pressure on other organizations to change.

Legitimacy lies at the core of each of the above views of institutional theory (Note 1). Suchman (1995) examined the multidimensionality of legitimacy as a construct and proposed a three-element form. The first element is the tension between continuity and credibility. Does persistence or meaning exist in equal degrees, or do they vary according to the situation? Thus, legitimacy affects not only how individuals understand the organization, but also how they act toward the organization itself. Second is the element of passive versus active support in the community within which the institution exists. Does the organization actively solicit support or passively accept acquiescence of its existence? The degree of social support necessary for maintaining existence determines how proactively an organization pursues active or passive legitimacy support from its milieu. Finally, the last element of legitimacy Suchman articulates is the tension between strategic and institutional views of legitimacy. The strategic approach views legitimacy as an operational resource extracted competitively from the environment and used to pursue organizational goals. Conversely, the institutional approach sees legitimacy as a constitutive belief system. The organization is granted legitimacy through and via the external institutions that construct and interpenetrate the firm. As Hoffman (2001: 136-137) noted, "the form of organizational response is as much a reflection of the institutional pressures that emerge from outside the organization as it is the form of organizational structure and culture that exist inside the organization." These external definers of the organization comprise the cultural milieu within which "the organization is built, how it is run, and, simultaneously, how it is understood and evaluated" (Suchman, 1995: 576). Therefore, new ventures, in selecting an organizational form, innately draw from legitimated institutional structures to conform to societal expectations. As managing through teams has gained greater acceptance, even at the executive level, it has developed the patina of legitimacy in contemporary management practices (Nadler and Ancona, 1992). New ventures may question whether they will gain greater legitimacy by organizing around executive team leadership or by following the founder's authority. Both dimensions are recognized legitimate means of organizational form, therefore the type of venture being founded may be even more influential in determining the institutional structure. Research on how institutional theory might better inform the development of new venture forms has developed recently. Sine and his co-researchers have examined how institutional forces may alter both the similarity and diversity of forms in the newly emerging independent power sector (Sine, Haveman, and Tolbert, 2005), how new venture founding team formalization, specialization, and administrative intensity realized increased performance relative to new ventures with a more organic structure (Sine, Mitsuhashi, and Kirsch, 2006), how formal certifications grant greater legitimacy to new ventures when sector industry legitimacy is lower than when the sector is established (Sine, David, and Mitsuhashi, 2007), and the role of social movements aid in establishing credibility and legitimacy for new sectors and, thus, in creating new opportunities for entrepreneurs (Hiatt, Sine, and Tolbert, 2009; Sine and Lee, 2009). Other research has looked at how entrepreneurs use symbolic management to acquire resources (Zott and Huy, 2007), the strategic formation of social networks by entrepreneurs (Stuart and Sorenson, 2007), and the role of legitimacy and status in gaining access to resources for new venture growth (Khaire, 2010).

As noted by March and Olsen (1984), everything that occurs within an organization is not necessarily purposive, every decision is not the result of a rational decision process, and organizational cultural controls can substitute for structural controls. Therefore, is institutionalism "a bridge too far" for the new venture to actively seek to achieve; is it a goal that can only be achieved by luck and the perspective of time; or, is it within management's ability to pursue/achieve even for a new venture in an emerging field?

\section{New Ventures, Organizational Structures, and Emerging Fields}

The concept of new ventures inherently is difficult to describe or define. The critical question is: At what point does a new venture come into existence? Temporality, thus, is the defining issue concerning birth and growth. Strategic management research generally has taken two tacks toward resolving the issue: for a private organization, enactment is the point when the organization is formally incorporated, and for the publicly traded business, the recognized inception date is the first day that the organization was publicly offered on a market. Yet, both of these methods of resolution result in overlooking the entrepreneur's point of opportunity recognition and the subsequent enactment of a structure to pursue that opportunity. Both incorporation and public offering of stock may be years away; however, the entrepreneur from the period of opportunity recognition until the formal establishment point (i.e., incorporation or public trading) is attempting to enact an organizational form that will allow for the success of the opportunity. For the organizational form to enhance the probability of success of the opportunity, it should evoke a sense of legitimacy from its stakeholders. 
Organizational theory struggles with the problem of describing and categorizing organizational forms (e.g., McKelvey, 1982; Rich, 1992; Sanchez, 1993). Romanelli (1991), in reviewing the literature on defining organizational forms, noted that there was no commonly accepted definition of the concept. A decade later, Foss (2002) reported that "in the 1999 Focused Issue of Organization Science on 'Coevolution of Strategy and New Organization Forms,' 10 papers deal[t] with new organizational forms, but not a single one of these define[d] their subject matter!" (p. 7). McKelvey and Aldrich (1983) noted that the majority of large organizations are admixtures of different forms, and Rich (1992) argued that firms' organizational form should be viewed as a multi-dimensional construct. Romanelli (1991: 81-82), recognizing the multi-dimensionality of the construct, offered a broad interpretation when she argued that "the concept of organizational form refers to those characteristics of an organization that identify it as a distinct entity and, at the same time, classify it as a member of a group of similar organizations."

While Romanelli's (1991) definition addressed the need to recognize the multi-dimensionality of organizational structure through the evocation of both form and identity, Pólos, Hannan, and Carroll (2002: 89) linked identity and form in more closely related terms. They argued that "forms must be considered as recognizable patterns that take on rule-like standing and get enforced by social agents." Thus, Pólos et al. see organizational form as an "external identity code" as it is the opinions and perceptions of outside actors that matter. Their use of the term code was deliberately chosen to simultaneously encompass two different connotations of articulated regulation: (1) a set of signals, as in a genetic code, and (2) a set of rules, as in a penal code. Therefore, relationships within the organization and between an organization and outsiders are central; the external identity code is enforced by its rule-like status. Those organizations that observably deviate from the external identity code thus face negative sanctions - a decline in outsiders' belief in the organization's legitimacy and reduced access to resources for the offending organization. As noted by Scott (2001: 147), new organizations "require the development of a social and political infrastructure that provides working rules, governance structures, and legitimacy." Legitimation consequently ameliorates the problem of maintaining flows of resources from the environment and enhances the ability of organizations to dissuade challenges to the organizational form (Hannan and Carroll, 1992).

Periods of rapid changes in social environment, either from technological innovations, sociocultural shifts, economic forces, and/or changes in the political-legal structure engender the rise of new ways of approaching issues. As these new approaches gather momentum and legitimacy, interest is drawn to the "emerging field" and research scientists begin their examination in an effort to understand the nascent field. This is contrasted to a stable or established field. Following the research on legitimacy by Suchman (1995), we define an established field as one that has achieved a "taken-for-granted" existence and form in its environment. Research on emerging fields indicates that administrative organization is not static, and routinely engages in innovation that requires study and understanding (Note 2). For the purpose of this paper, an emerging field is one whereby new modes of governing transactions arise, especially with respect to the internal structure of the organization and how organizations configure interchanges with other organizations. Transactions may consist of both economic- and/or knowledge-based exchanges within and between organizations.

\section{New Ventures Entering Established Organizational Fields}

A new venture either recreates a business that currently exists (e.g., another florist shop opening this year) or seeks to establish a business that has not existed before (e.g., software applications for "smart" cell phones in the late-2000s). Launching any new venture presents challenges, yet new ventures introduced into established organizational fields do not confront the necessity of ascertaining an acceptable institutional form; the socially accepted form already exists. Selznick (1949: 48) likened a nascent organization's search for an institutional form and the organizational form enacted as a "quest for an ideology, for doctrinal nourishment" allowing the organization to survive, grow, and eventually prosper. Organizations recreating a proven institutional structure (i.e., those organizations established in the stable context of previously legitimated forms) thus should have the shield of previously accepted form buffering the force of legitimization concerns. The firm recreating a previously legitimated structure therefore draws on the past successes of similar organizations it selects to model in its own quest for societal (institutional) acceptance.

Expanding beyond organization administrative functions, all aspects of the organization require the same requisite attention to efficiency which drives organizations to a paradox of change that results in increased homogeneity across organizational forms (DiMaggio and Powell, 1983; Haveman and Rao, 1997). Nascent organizations are not immune from this confounding prescription of vitalization resulting in a generic business form. New ventures seek an organizational structure that allows them to access, accumulate, control, and exploit resources, and that capability comes through accessing forms that do not confound the already established organizations from which the nascent 
entity must draw its resources. The new venture, entering a highly structured organizational context, in its efforts to rationally confront uncertainty and constraint often results in the aggregate with a homogenized structure (DiMaggio and Powell, 1983). In other words, the new venture, which is entering a well-established field, adopts the prevailing structure of the field in order to gain legitimacy (Khaire, 2010) and position itself to access and supply resources to other organizations in the environment. Thus, organizations are not driven singularly by a need to replicate the forms of their equivalent (competitive) organizations; they must take on an organizational form that allows them to exist within the totality of their environment - their form must achieve a measure of complementariness to all organizations within their network (Sine, David, and Mitsuhashi, 2007). Therefore, this rationalization of form pushes out forms that are non-bureaucratic; and, institutional isomorphism drives the adoption of organizational structures for those new ventures entering into well-established fields.

Institutional isomorphism was first conceived of as a typology by DiMaggio and Powell (1983). They postulated three mechanisms of institutionalism through which isomorphic change occurs. The first, coercive isomorphism, arises from the issue of political influence and the search for legitimacy. Politics, being the exercise of influence over matters of mutual concern, are the joint formal and informal pressures that organizations within the new venture's environment place upon the neophyte entity to adopt a particular sanctioned structure (Ruef, 2000). Pressures exist as a force (a specific structure is required to enable the new venture to access needed resources), as persuasion (in order to receive commitments from certain firms a recommendation for structural complementariness is proffered), or as a government mandate (to operate in a particular field specific regulatory policies must be implemented by the firm).

Mimetic isomorphism, the second mechanism, is a standard response to uncertainty and environmental ambiguity. Modeling (DiMaggio and Powell, 1983) is a reaction to the uncertainty that the firm faces. Examining the means by which established organizations have coped with the ambiguity, the new venture seeks to replicate the behaviors of successful (in that they are survivor) firms and match the form that the environment has accepted (Cyert and March, 1963; Hannan and Freeman, 1977). Decision makers react to uncertainty and ambiguity by substituting previously successful forms into situations that are similar and maintain legitimacy via the act of engaging in activities with significance to other members of the organizational environment thus providing a rational and legitimate account (Bielby and Bielby, 1994).

Finally, normative isomorphism reflects the professionalization of organizational standards. Professionalization arises from two distinct aspects of institutional isomorphism. The first is the homogenization that occurs through the cognitive schemas and legitimation established through formal university education, while the second materializes through the span or web of professional networks built between organizational actors. Organizational executives, including new venture executives, admix with each other during professional associations and other conclaves; they rely on similar sources of information such as trade journals; they recruit from the same professional labor pool and oftentimes engage the same professional industry consultants. This reductionism in information sources fosters shared perspectives of the current situation and shared expectations for the future (Reger and Huff, 1993). Professional networks eventuate in shared standards and outlook among organizational players as they filter among the myriad organizations within the environment. This professional homogenization results in a tendency to view problems the same way, a proclivity for policies to be replicated across organizations, and structure and procedures to mime those normatively sanctioned (Bozeman and Rainey, 1999; DiMaggio and Powell, 1983). Thus, normative isomorphism results in decision processes of new venture founders, operating within established, structured industries, to repeat those of other entities that have the mark of legitimation through professional standardization. Therefore, organizational structure will be widely shared by organizational actors within an industry, rather than each actor holding sui generis cognitions of organizational structure (Reger and Huff, 1993), and new venture executives will rationalize the coercive, mimetic, and normative forms to reflect the established industry structures.

The analysis of the role of legitimization and organizational fields in the selection of institutional forms of new ventures in established organizational fields thus extends institutional theory to new ventures, and broadens new venture theory to include institutional processes and constructs (e.g., isomorphism). The preceding explication thus conflates the two streams in developing an understanding of the influence of legitimization on an established organizational field. Isomorphism of form arises as an established form has demonstrated how to garner resources and increase the perceived likelihood of survival. Simply stated, the more something is adopted, the more likely it is to be adopted. The discussion of the foregoing three mechanisms of institutional isomorphism leads to the proposition concerning the structural form that a new venture entering into an established field will take:

Proposition 1: New ventures entering into already well-structured fields will adopt the institutional structure legitimated by institutional isomorphism. 


\section{New Ventures in New Fields}

New organizations building or entering new organizational fields face the prospect of few established routines or structures from which to establish organizational legitimacy (Crossan, Lane and White, 1999). There is no institutional form from which to draw legitimacy or organizational memory to construct the organization. Thus, because of their small size, their currently non-legitimated form, and their search for environmental acceptance, new ventures in nascent fields engage in imitation of forms legitimated in other environments, routines that have succeeded in previously experienced venues, and use heuristics derived from professional associations. Therefore, to achieve legitimacy, these new ventures will pursue activities that mimic ritually significant processes to outsiders whom the new venture executives desire to impress (Bielby and Bielby, 1994; Suchman, 1995). As noted by Selznick (1949: 260):

It may not be necessary actually to share power: the creation of a "front" or the open incorporation of accepted elements into the structure of the organization may suffice. In this way, an aura of respectability will be gradually transferred from the coöpted elements to the organization as a whole.

Entrepreneurs' opportunities often have their seeds in pre-existing organizations; the exploitation of new venture opportunities often relies on the individual's prior knowledge about markets, products, and processes (Shane, 2000). These processes provide "prudent, rational, and legitimate accounts" of the entrepreneur's actions (Meyer and Rowan, 1977). Yet, while the ritually significant actions proved their efficacy in other established fields, their value is unproven in the emergent field. Actions that have thus proven efficacious in an established field and are replicated by the entrepreneur in an emergent field we describe as symbolic actions to reflect the mimicking of actions that have achieved a taken-for-granted status in a known context however are still unproven in their new context. By engaging in these prudent, rational, and legitimate accounts, new venture executives use the institutional devices of reputation and imitation to reassure both exogenous and endogenous constituencies that their actions are not only appropriate, but that they are also legitimate and rational (Bielby and Bielby, 1994; Zott and Huy, 2007).

Nascent organizational fields calling for new organizational forms do not occur with regularity. Schrag (quoted in Schendel, 2007: 54) noted that "creation is not reducible to problem-solving; it requires interpretation and imagination that draws from 'tacit' knowledge; it requires action and not just decision making; it sees rationality as performative and not simply cognitive; and it is constructive rather than simply rule-governed." Schumpeter (1942) envisaged new organization forms creation as occurring during "gales of creative destruction." Whether the entrepreneur forming creation opportunities begets the gales or the gales beget opportunities (the opportunity creation versus opportunity discovery issue), these creative gales sweeping through an economy allow unorthodox/non-legitimated organizational forms to gain acceptance and legitimacy where before no similar structure/organization existed. These new ventures in new fields and their non-traditional forms stand in stark contrast to the conventional organizational forms mimicked by new ventures entering fields with already well-established institutional forms. As these unconventional new organizational structures contend for adoption, new institutional forms arise.

New emergent technologies, expanded communications, and faster transportation capabilities are a few of the energies that create the gales of creative destruction within and across societies. The broad acceptance of Internet technologies enacted an opportunity for new organizational forms to emerge in new markets and possibly transform established markets. Yet, these new organizational entities that exploited the capabilities of the Internet had no organizational edifice upon which to pattern their own nascent structure.

Amazon.com, though not the first to adopt the new technology, became a leader in implementing the capabilities arising from the new technology (Krishnamurthy, 2002; Deutschman, 2004). Through the organization's definitional emergence, the influence of virtual businesses impacted a rapidly broadening swath of American consumer and business life. Without an organizational pattern, Amazon.com was free to adapt selected aspects of other myriad organizational structural forms into a single whole that was capable of meeting the reality of the new environment in which the firm desired to compete. The institutional isomorphism pressures that faced Amazon.com were parried via the selective acceptance of those institutional forces that were rational for a new environment's structure. Therefore, this new venture in a new field engaged in activities to mimic ritually significant processes for outside consumption, such as the development of a typical bureaucratic management structure while eschewing coercive and mimetic mechanisms that called for the establishment of "brick and mortar" structures in each location in which it desired to anchor itself. Rather, Amazon.com as an entrepreneurial endeavor presented itself to selected capitalists for funding (Schumpeter, 1942) commencing its legitimization via a small group of venture capitalists and anchored itself in cyberspace and approached the task of legitimatization through the "prudent, rational, and legitimate methods" of mass advertising (Krishnamurthy, 2002; Deutschman, 2004). These efforts also provided a means to bypass some of the 
constraining professional mechanisms through an appeal to more youthful stock market analysts who were assumed to be more technologically savvy and more willing to accept a non-legitimate organizational form as being a rational adaptation to a novel entrepreneurial moment in the unfolding of a new technology. Additionally, the reliance on the Internet for sales defined the constituency who recursively defined and shaped the form of Amazon.com (Selznick, 1949). The public's acceptance of a cyber-bookstore granted the Amazon.com structure a rapid institutional legitimacy.

Unintentionally assisting in Amazon.com management's efforts to establish an institutionally legitimate form were the pioneering efforts of $E^{*}$ Trade, a stock brokerage firm that had existed since shortly after the deregulation of stock brokerages in the late 1970s. Founded as a service bureau in 1982, the early $\mathrm{E}^{*}$ Trade provided online quote and trading services to conventional "brick and mortar" brokerages (Hofman, 2000). Continuing to develop in an evolutionary/realist fashion over several years (Aldrich and Kenworthy, 1999; Campbell, 1960), E*Trade management maintained a conventional, organizational (legitimate) form for providing services. Cost and lack of individual recognition of capabilities hindered computer technology, a potential technological solution, from establishing itself as a legitimated institutional form. A confluence of technological and societal forces in conjunction with the opportunity recognition by E*Trade's management made possible a new organizational form as the personal computer gained broader acceptance over time. Its subsequent popular market intrusion allowed it to reach the minimum saturation investiture necessary for widespread personal and commercial adoption. Once the minimum technological adoption weight had been achieved in 1992, E*Trade, the virtual brokerage service, was initiated and began to offer online investing services through America Online and CompuServe (two other organizations striving to also impart institutional legitimacy to a nascent technological ontology). E*Trade established itself as an independent and legitimated leader in providing "anytime, anywhere, any device" access to financial information and transaction capabilities. Recognizing that legitimacy is not a nominal value but rather exists along a continuum (Zariski, 1986), E*Trade continued to add options, choices, and capabilities to its roster of services in an effort to establish its legitimacy as equivalent to the organizational legitimacy previously earned by the contemporary "brick and mortar" brokerage firms. Thus, $\mathrm{E}^{*}$ Trade had evolved a new institutionally legitimate organizational form by evolving with the technology while maintaining a symbolic legitimate form.

As with Amazon.com, E*Trade's success in providing a new service in a new organizational setting that generally exceeded minimal expectations allowed an institutional form to develop - allowed a legitimate form of service to be established to function in the neo-business space. Thus, a legitimate form was established, similar to the M-Form being independently and almost concurrently adopted by industrial and bureaucratic organizations in the early $20^{\text {th }}$ Century (Chandler, 1962). The "dot.com" boom erupted, and the legitimate institutional form had been framed by the likes of Amazon.com, E*Trade, and eBay. Each had separately come to the concurrent realization that the new organizational form did not require physical structures to create and legitimate an actual business. The capability of electronic connections to establish the reality of the organizational form generated the legitimacy of the new venture. The new organizational forms' executives had rationally allowed the environment to build the rules by which legitimation was ensured. With legitimation, the new institutional forms became an almost self-replicating entity (Suchman, 1995). The result of achieving organizational legitimacy, therefore, is that little continuous investment in structuration mobilization is required.

The perceived environmental characteristics emerging from the cognitive and organizational schemas of new venture executives willing to forswear accepted institutional form initiated strategic design actions that lead to new legitimated forms (Dijksterhuis, Van den Bosch and Volverda, 1999). They recognized that rationality resided in "rules assuring that participant will behave in ways calculated to achieve desired objectives, [and] in control arrangements that evaluate performance and detect deviance" (Dijksterhuis, Van den Bosch and Volverda, 1999: 573). Entrepreneurs are likely to have professional links within the market or industry where an opportunity is being exploited (Shane, 2000). These individuals will often have gained much of their knowledge and information from being embedded within the market or industry in which the opportunity was discovered (Alvarez and Barney, 2007). Yet, what is prudent and rational in a legitimate field or market is by definition illegitimate and not prudent when creating a new field (Kuhn, 1962). Again, in order to achieve legitimacy, these new ventures in nascent organizational forms pursue activities that ritually mimic significant processes that outsiders recognize as similar to (and legitimate approximations of) already accepted behaviors (Zott and Huy, 20007). The prudent, rational, and legitimate actions enacted by the new ventures' executives garner sufficient time and suspension of disbelief in the new organizational structure for it to achieve its own legitimate standing. Whereas both exogenous and endogenous constituencies are willing to accept an imitation of a legitimate form (i.e., symbolic institutionalism) until the actual form has established itself as not only an appropriate but also as a legitimate and rational organizational choice 
(Bielby and Bielby, 1994), these internal and external constituencies are only willing to accept a non-legitimated form for the period of time necessary for contending forms to demonstrate one or more contending organizational structures' ability to establish an institutional standard. Legitimacy affects not only how the society behaves toward organizations, but also additionally how constituencies understand them in their environment (Suchman, 1995; Zott and Huy, 2007).

From the above discussion, the argument is proposed that new ventures in inchoate organizational fields, lacking accepted/legitimate structures from which to enact institutional isomorphic replication, nevertheless engage in symbolic institutional conduct. Symbolic institutional conduct, we argue, will include such actions as evocative behaviors, habitualized actions, heuristics, and engagement in rational activities with social significance to evoke a suspension of non-legitimacy belief while the new venture establishes its structure as an acceptable institutional form for its emerging milieu. The preceding explication thus leads to the following propositions for new ventures in new organizational fields for which an institutional form does not exist:

Proposition 2a: New ventures entering into nascent, unstructured fields will utilize a symbolic-mimetic isomorphism to allay the ambiguity and uncertainty of its organizational structure to placate endogenous and exogenous actors engaged in evaluating whether the organization achieves legitimacy.

Proposition 2b: New ventures entering into nascent, unstructured fields will utilize a symbolic-normative isomorphism to allay the professional equivocality by exogenous professionals concerning the new entity's organizational structure while evaluating whether the organization achieves legitimacy.

Proposition 2c: New ventures entering into nascent, unstructured fields will eschew symbolic-coercive isomorphism, as an established replicable organizational form has not been established in the new environment.

This bifurcation of the constituencies' reaction to the new venture presents a dilemma for new venture management. Executives seeking to establish a nascent organizational firm as a new legitimate form for the emerging field can stress the neo-entity's differentiation from other organizational forms that no longer have comparable social legitimization (Samu, Krishnan and Smith, 1999). This strategy entails the risk of failing to achieve new-form legitimization. The flip side to the differentiation strategy is the path of seeking societal belief in similarity with previously established organizational forms (Samu, et al., 1999). These new entity actors thus engage in symbolic institutional conduct in order to placate environmental institutional forces while the nascent organizational form establishes itself as an equivalent organizational (legitimate) form for accomplishing societal missions and needs. The former strategy, differentiation, was practiced extensively by E*Trade, as it marketed itself as "America's Electronic Brokerage" to establish itself as a unique organization among all the stultified traditional brokerage firms. Its efforts at establishing the electronic brokerage firm as a legitimate form were successful in that, though resisted for several years, traditional brokerages were forced to adopt some form of electronic trading for their customers to prevent defections from their client base. Table 1 briefly examines multiple new ventures' legitimization action responses addressed to the mimetic, normative, and coercive forces confronting their administrative organization legitimization and institutionalization.

$<$ Insert Table 1 Here $>$

The latter strategy, similarity, was engaged in by Amazon.com in its efforts to establish itself as equivalent to any bookstore but with supplemental features. Amazon.com stressed that it had the same stock yet with a broader and deeper resource base. Additionally, it stressed that its reliance on package delivery services ensured that books were delivered essentially as soon as the reader desired. Amazon.com's ability to meet customers' needs whether residing in rural America or overseas allowed it to enjoy the legitimacy of established traditional booksellers while building a societal schema that electronic booksellers are equally legitimate organizational forms as the traditional booksellers. Again, traditional "brick and mortar" booksellers were unable to prevent a new organizational form emerging to challenge their near-monopoly. The traditional booksellers, though recognizing that a new milieu had erupted, resisted adapting their organizational structure to meet the emerging needs of customers. Like E*Trade, Amazon.com's legitimated form forced traditional firms to provide additional services in order to maintain their own legitimacy. By stressing similarity, Amazon.com, while still a nascent (and not yet taken-for-granted) organizational form, redefined the minimum legitimate services an organization must provide in order to remain legitimate on a national scale. Thus, new ventures in emerging fields, even unsuccessful organizations, may establish a value proposition that customers expect, even of those organizations wedded to the established institutional form. The dot-com boom and bust period of the late 1990s and early 2000s provides numerous examples of changed value propositions such as theGlobe.com, which was an online social networking site established before both Facebook and MySpace that failed yet established a paradigm for social networking, and pets.com, which was an online pet supply store. In each of these two examples, 
customers adjusted their minimum acceptable value propositions for organizations that survived based on value propositions offered by failed organizations. From this, the proposition follows:

Proposition 3: New ventures, having established a new value proposition in a nascent, unstructured field, act as a mimetic isomorphic force upon established organizations that are forced to adopt and adapt their structures to incorporate the newly societally-embraced organizational attributes.

It is expected that established organizations with intact, legitimate, functioning institutional forms actively resist pressures for mimetic isomorphism in the face of the environmental ambiguity and uncertainty of new fields emerging. The tendency to "whistle past the graveyard" will assert itself as established organizations rationalize that newly emerging fields are but aberrations that will shortly revert to known forms. Established firms will elide the pressure of unexpected structural changes in their attempt to maintain command over their environment. However, emerging new fields (with their concomitant new organizational structures) entail environmental uncertainty that cannot be controlled through homological certitude. Yet, it is only through the mechanisms of market forces for commercial firms and societal forces for non-profit organizations combined with the normative exchange of professional interactions and associations from emerging organizations to established organizations will the latter begin the adoption of structural overhaul and change. From the above discussion, it follows:

Proposition 4: Established firms will resist adoption of non-legitimated organizational structural changes in the face of uncertainty and ambiguity until normative forces combine with mimetic isomorphism to instigate evolutionary changes in the established firms.

\section{Discussion and Conclusion}

Institutional theory has long been established as an explanation for the tendency toward homogenization of organizational structures. The dominant concept of institutional theory is the organization's search for legitimacy. As opined by Suchman (1995), legitimacy is a social construct that reflects congruence between the shared beliefs of some exogenous and/or endogenous social group and the behaviors of the management team of the legitimated entity. Thus, social groups' actions toward an organization are a reflection of the group's understanding of the adopted organizational form. Yet, throughout the discussion of how and why groups of actors gravitate toward a similar, legitimated organizational form, institutional theory has failed to explicate how new ventures enact an organizational form that will allow them to successfully interact with their environment.

The preceding discussion offers a foundational view that new ventures, in fact, enact a structure that reflects whether the organization is entering an established organizational field or whether a new organizational form is required to match an emerging field. The gales of creative destruction (Schumpeter, 1942) offer the opportunity to new ventures to build their structure to match the new venture's strategy required for the new environment (Chandler, 1962). And, yet, institutional theory, we posit, offers compelling theoretical arguments for how new ventures choose the form to enact. From the organizational form that is enacted by new ventures, the legitimation process begins anew for every organizational structure in existence.

If the enacted form of the new venture reflects no more than the simple coercive, mimetic, and normative isomorphism expectations of current structures, then the validation of the contemporary organizational gestalt requires only the most cursory re-validation and legitimation. It is the new environment, the emerging fields, that require new ventures to persuade their external environment and internal players to suspend demands for legitimation until the organizational form, as enacted, establishes its ability to survive in its environment and provide benefits to its stakeholders (Zott and Huy, 2007). Through the acts of symbolic institutional conduct, the new venture in new fields thus gains sufficient time to earn legitimate institutional acceptance.

During the stage of resorting to symbolic institutional actions to sustain the organizational form, the new ventures are thus creating pressures on the already legitimated structural forms. As the nascent, emerging form gains societal acceptance on its path to institutionalization, established organizational forms are then compelled to re-verify and re-legitimate their own institutional structure. The uncertainty and ambiguity of emerging fields, changing environments, and new forms arising imbue established firms with a tendency to champion the old form as the only legitimate (correct) structure. In other words, the established firm looks over its shoulder as it marches into the future in order that it may maintain its vision as long as possible on the familiar, on the safe, and on the proven structural form. Yet, it is the pressure of the emerging form seeking legitimation on its path to institutionalization, that forces gestalt breaking cognitive schemas within accepted institutional forms.

New ventures' structural forms are enacted through the process of institutionalization. Those arising in established fields follow precisely the path articulated by DiMaggio and Powell (1983). More interestingly, though, the new 
ventures arising in nascent fields still are impacted by the dictates of coercive, mimetic, and normative isomorphism. Yet, the new ventures achieve independence of old forms by engaging in symbolic institutional actions, in imitation of legitimated forms from other environments, routines that succeeded in previously experienced venues, and by heuristics mapped by professional associations. Thus, on their path to achieving legitimacy, new ventures pursue activities that mimic ritually significant institutional processes until the environment and society recognize and acknowledge the nascent organization's own validity.

The above exposition is but one step along the path of utilizing institutional theory to explicate the method by which organizational legitimacy is achieved for new ventures as they enact their structural form. Far from seeing institutional theory as singularly deterministic, an iron cage that solely determines and ratifies organizational form, we posit that our theoretical extension adds a nuanced complexity that expands institutional theory to encompass the earliest period of an organization's lifecycle. Whereas former discussions of institutional theory constrained organizations in their choice of institutional forms and thus only explained forces that led established firms to a homogenized structural sameness, we have argued that institutional theory provides valuable insights into forces (and choices) that determine relevant mechanisms through which management teams of new ventures evolve their organization's structural form. In our extension of institutional theory, new venture management consciously can select institutional isomorphic actions, pursue a path of symbolic institutional conduct, or combine both actual institutional isomorphic action with symbolic institutional conduct to create an institutionally acceptable form that conforms to their situational specificity, either a new venture in an established field or, even more distinctively, a new venture in an emerging field with no legitimated form to normatively mimic. This further extension of institutional theory thus provides the researcher with a means to theoretically examine an aspect of organizational research that only recently has lain within the consideration of institutional theory - the method by which a new venture organization achieves a structure that is legitimate, both strategically and institutionally (Suchman, 1995).

The field of new venture research, both domestic and international, is expanding rapidly and requires, as most social science fields do, development to and extensions of theoretical underpinnings (McDougall and Robinson, 1990; McDougall, Shane and Oviatt, 1994) to support more robust empirical examinations of, in this case, business venturing. By incorporating institutional theory into the considerations of how new ventures decide on and achieve their organizational form, a more complex and dense view of managerial motivations in arriving at their organization's structural form can be explored. For the practice of new venture management, this theoretical discussion develops an overarching framework of questions: Which institutional isomorphic actions are necessary for new venture firm survival, which actions are best observed as symbolic institutional actions, and how are the two distinguished? There is a process of mimicking some aspects of traditional form (management structure) but resisting others (brick and mortar). This process seems to be a balance between differentiation and similarity strategies - an and/both vs. and either/or approach. How do new ventures determine and achieve this balance?

The principal objective of this theoretical discussion is to invigorate a discussion of possible extensions to institutional theory to cover the earliest period in an organization's life - from the recognition of the entrepreneurial opportunity to the new venture's legitimizing structuration - and the actions in which new ventures must engage in order to achieve environmental survival, acceptance, and growth.

\section{References}

Aldrich, H.E., \& Kenworthy, A.L. (1999). The accidental entrepreneur: Campbellian antinomies and organizational foundings. In J.A.C. Baum \& B. McKelvey (Eds.), Variations in Organization Science: In Honor of Donald T. Campbell (pp. 19-33). Thousand Oaks, CA: Sage. http://dx.doi.org/10.4135/9781452204703.n2

Aldrich, H.E., \& Fiol, C.M. (1994). Fools rush in? The institutional context of industry creation. Academy of Management Review, 19(4), 645-670.

Alvarez, S.A., \& Barney, J.B. (2007). Discovery and creation: Alternative theories of entrepreneurial action. Strategic Entrepreneurship Journal, 1(1-2), 11-26. http://dx.doi.org/10.1002/sej.4

Berger, P.L., \& Luckmann, T. (1967). The social construction of reality. New York: Doubleday.

Bielby, W.T., \& Bielby, D.D. (1994). "All hits are flukes": Institutionalized decision making and the rhetoric of network prime-time program development. American Journal of Sociology, 99(5), 1287-1313. http://dx.doi.org/10.1086/230412

Blau, P.M. (1955). The dynamics of bureaucracy. Chicago: University of Chicago Press. 
Bozeman, B., \& Rainey, H.G. (1998). Organizational rules and the "bureaucratic personality". American Journal of Political Science, 42(1), 163-189. http://dx.doi.org/10.2307/2991751

Campbell, D.T. (1960). Blind variation and selective retention in creative thought as in other knowledge processes. Psychological Review, 67(6), 380-400. http://dx.doi.org/10.1037/h0040373

Chandler, A.D. (1962). Strategy and structure: Chapters in the history of the American industrial enterprise. Cambridge, MA: MIT Press.

Crossan, M.M., Lane, H.W., \& White, R.E. (1999). An organizational learning framework: From intuition to institution. Academy of Management Review, 24(3), 522-537.

Cyert, R.M., \& March, J.G. (1963). A behavioral theory of the firm. Englewood Cliffs, NJ: Prentice-Hall.

Deutschman, A. (2004, August). Inside the mind of Jeff Bezos. Fast Company, 85(8), 52-55.

Dijksterhuis, M.S., Van den Bosch, F.A.J., \& Volberda, H.W. (1999). Where do new organizational forms come from? Management logics as a source of coevolution. Organization Science, 10(5), 569-582. http://dx.doi.org/10.1287/orsc.10.5.569

DiMaggio, P.J., \& Powell, W.W. (1983, April). The iron cage revisited: Institutional isomorphism and collective rationality in organizational fields. American Sociological Review, 48, 147-160. http://dx.doi.org/10.2307/2095101

Gouldner, A.W. (1954). Patterns of industrial bureaucracy. Glencoe, IL: Free Press.

Hannan, M.T., \& Freeman, J.H. (1977). The population ecology of organizations. American Journal of Sociology, 82, 929-64. http://dx.doi.org/10.1086/226424

Hannan, M.T., \& Freeman, J.H. (1989). Organizational Ecology. Cambridge, MA: Harvard University Press.

Haveman, H.A., \& Rao, H. (1997). Structuring a theory of moral sentiments: Institutional and organizational coevolution in the early thrift industry. American Journal of Sociology, 102(6), 1606-1651. http://dx.doi.org/10.1086/231128

Hiatt, S.R., Sine, W.D., \& Tolbert, P.S. (2009). From Pabst to Pepsi: The deinstitutionalization of social practices and the creation of entrepreneurial opportunities. Administrative Science Quarterly, 54(4), 635-667. http://dx.doi.org/10.2189/asqu.2009.54.4.635

Hoffman, A.J. (2001). Linking organizational and field level analysis: The diffusion of corporate environmental practice. Organization \& Environment, 14(2), 133-156. http://dx.doi.org/10.1177/1086026601142001

Hofman, M. (2000, October 17). Let's get physical. Inc., 22(15), 195-196.

Krishnamurthy, S. (2002). E-Commerce management: Text and cases. Mason, OH: South-Western College Publishing.

Kuhn, T.S. (1962). The structure of scientific revolutions. Chicago: The University of Chicago Press.

Lipset, S.M., Trow, M.A., \& Coleman, J.S. (1956). Union democracy. Glencoe, IL: Free Press.

Lord, R.G., \& Kernan, M.C. (1987). Scripts as determinants of purposeful behavior in organizations. Academy of Management Review, 12(2), 265-277.

March, J.G., \& Olsen, J.P. (1984). The new institutionalism: Organizational factors in political life. American Political Science Review, 78, 734-749. http://dx.doi.org/10.2307/1961840

McDougall, P.P., \& Robinson, R.B. (1987). New venture strategies: An empirical identification of eight distinct strategic orientations. Academy of Management Proceedings, pp. 72-81.

McDougall, P.P., Shane, S., \& Oviatt, B.M. (1994). Explaining the formation of international new ventures: The limits of theories from international business research. Journal of Business Venturing, 9, 469-487. http://dx.doi.org/10.1016/0883-9026(94)90017-5

Meyer, J.W., \& Rowan, B. (1977). Institutional organizations: Formal structure as myth and ceremony. American Journal of Sociology, 83, 340-363. http://dx.doi.org/10.1086/226550

Nadler, D.A., \& Ancona, D. (1992). Teamwork at the top: Creating executive teams that work. In David A. Nadler, et al. (Eds.), Organizational Architecture (pp. 209-231). New York: Jossey-Bass.

Reger, R.K., \& Huff, A.S. (1993). Strategic groups: A cognitive perspective. Strategic Management Journal, 14(1), 103-124. http://dx.doi.org/10.1002/smj.4250140203 
Roberts, P.W., \& Greenwood, R. (1997). Integrating transaction cost and institutional theories: Toward a constrained-efficiency framework for understanding organizational design adoption. Academy of Management Review, 22(2), 346-373.

Ruef, M. (2000). The emergence of organizational forms: A community ecology approach. American Journal of Sociology, 106(3), 658-714. http://dx.doi.org/10.1086/318963

Samu, S., Krishnan, H.S., \& Smith, R.E. (1999). Using advertising alliances for new product introduction: Interactions between product complementarity and promotional strategies. Journal of Marketing, 63, 57-74. http://dx.doi.org/10.2307/1252001

Schendel, D. (2007). Risk and Uncertainty. Strategic Entrepreneurship Journal, 1(1-2), 54. http://dx.doi.org/10.1002/sej.17

Schumpeter, J.A. (1942). Capitalism, socialism, and democracy. New York: Harper \& Brothers.

Scott, W.R. (1987). The adolescence of institutional theory. Administrative Science Quarterly, 32, 493-511. http://dx.doi.org/10.2307/2392880

Scott, W.R. (2001). Institutions and organizations ( $2^{\text {nd }}$ ed.). Thousand Oaks, CA: Sage Publications.

Selznick, P. (1949). TVA and the grass roots: A study of politics and organization. Berkeley, CA: University of California Press.

Selznick, P. (1957). Leadership in administration. New York: Harper \& Row.

Shane S. (2000). Prior knowledge and the discovery of entrepreneurial opportunities. Organization Science, 11(4), 448-470. http://dx.doi.org/10.1287/orsc.11.4.448.14602

Sine, W.D., \& Lee, B.H. (2009). Tilting at windmills? The environmental movement and the emergence of the U.S. wind energy sector. Administrative Science Quarterly, 54, 123-155. http://dx.doi.org/10.2189/asqu.2009.54.1.123

Sine, W.D., David, R.J., \& Mitsuhashi, H. (2007). From plan to plant: Effects of certification on operational start-up in the emergent independent power sector. Organization Science, 18(4), 578-594. http://dx.doi.org/10.1287/orsc.1070.0300

Sine, W.D., Haveman, H.A., \& Tolbert, P.S. (2005). Risky business? Entrepreneurship in the new independent power sector. Administrative Science Quarterly, 50, 200-232.

Sine, W.D., Haveman, H.A., \& Tolbert, P.S. (2005). Risky business? Entrepreneurship in the new independent-power sector. Administrative Science Quarterly, 50, 200-232.

Sine, W.D., Mitsuhashi, H., \& Kirsch, D.A. (2006). Revisiting Burns and Stalker: Formal structure and new venture performance in emerging economic sectors. Academy of Management Journal, 49(1), 121-132. http://dx.doi.org/10.5465/AMJ.2006.20785590

Sorenson, O., \& Stuart, T.E. (2008). Entrepreneurship: A field of dreams? In James E. Walsh and Arthur P. Brief (Eds.), The Academy of Management Annals (Vol. 2, pp. 517-543). London: Routledge.

Stuart, T.E., \& Sorenson, O. (2007). Strategic networks and entrepreneurial ventures. Strategic Entrepreneurship Journal, 1(3-4), 211-227. http://dx.doi.org/10.1002/sej.18

Suchman, M.C. (1995). Managing legitimacy: Strategic and institutional approaches. Academy of Management Review, 20(3), 571-610.

Tolbert, P.S., \& Zucker, L.G. (1983). Institutional sources of change in formal structure of organizations: The diffusion of civil service reform, 1880-1935. Administrative Science Quarterly, 28, 22-39. http://dx.doi.org/10.2307/2392383

Weick, K.E. (1979). The Social Psychology of Organizing. Reading, MA: Addison-Wesley.

Zariski, R. (1986). The legitimacy of opposition parties in democratic political systems: A new use for an old concept. Western Political Quarterly, 39(1), 29-47. http://dx.doi.org/10.2307/448412

Zott, C., \& Huy, Q.N. (2007). How entrepreneurs use symbolic management to acquire resources. Administrative Science Quarterly, 52(1), 70-105. http://dx.doi.org/10.2189/asqu.52.1.70

Zucker, L.G. (1983). Organizations as institutions. In Samuel B. Bacharach (Ed.), Research in the Sociology of Organizations, (Vol. 2, pp.1-47). Greenwich, CT: JAI Press. 


\section{Notes}

Note 1. Legitimacy, for the purpose of the remainder of this discussion, draws upon the inclusive, broad-based definition adopted by Suchman (1995). Legitimacy, he argues, is "a generalized assumption or perception that the actions of an entity are desirable, proper, or appropriate within some socially constructed system of norms, values, beliefs, and definitions" (p. 574). Legitimacy is a perception or assumption in that it represents a reaction of observers to the organization as they see it; thus, legitimacy is possessed objectively, yet created subjectively. For a full explication of legitimacy and each of its constitutive parts, Suchman's Managing Legitimacy: Strategic and Institutional Approaches addresses fully the three primary modes of legitimacy: "pragmatic, based on audience self-interest; moral, based on normative approval; and, cognitive, based on comprehensibility and taken-for-grantedness" (p. 571).

Note 2. The concept of an "emerging field," while frequently invoked in academic literature, is one undefined in that literature. A 2008 survey of the Business Source Premier and JSTOR databases resulted in 500+ separate academic articles using one of the terms "emerging field" or "emergent field." Though the terms are commonly used, none of the articles, whether referring to new administrative forms, new ventures, or new avenues of academic interest, conceptual defined its use of the term.

Table 1. New venture legitimization force responses

\begin{tabular}{|c|c|c|c|}
\hline New Venture & $\begin{array}{c}\text { Response to } \\
\text { Coercive Isomorphic } \\
\text { Forces }\end{array}$ & $\begin{array}{c}\text { Response to } \\
\text { Mimetic Isomorphic } \\
\text { Forces }\end{array}$ & $\begin{array}{c}\text { Response to } \\
\text { Normative Isomorphic } \\
\text { Forces }\end{array}$ \\
\hline In a New Field & $\begin{array}{l}\text { (1877) John Wanamaker opened "The } \\
\text { Grand Depot" a six story round } \\
\text { department store in Philadelphia to } \\
\text { capture the vast power of buying } \\
\text { wholesale to cut costs in order to } \\
\text { reduce retail prices (Ershkowicz, } \\
\text { 1999). }\end{array}$ & $\begin{array}{l}\text { (1872) Montgomery Ward sells } \\
\text { goods directly to customers via } \\
\text { printed catalogue vice using traveling } \\
\text { salesmen. Catalogue provided printed } \\
\text { description supplemented by a } \\
\text { picture to mimic traveling salesmen's } \\
\text { samples. }\end{array}$ & $\begin{array}{l}\text { (1994) Amazon.com receives } \\
\text { venture capital funding from } \\
\text { Kleiner Perkins Caufield \& } \\
\text { Byers for new business by } \\
\text { emphasizing its ability to } \\
\text { maintain a greater title list } \\
\text { than conventional, successful } \\
\text { brick-and-mortar bookstores } \\
\text { and mail-order catalogs } \\
\text { (typically } 200,000 \text { titles). }\end{array}$ \\
\hline $\begin{array}{l}\text { In an } \\
\text { Established } \\
\text { Field }\end{array}$ & $\begin{array}{l}\text { (1962) Sam Walton opens discount } \\
\text { department store, Wal-Mart, (capturing } \\
\text { the power of buying wholesale to cut } \\
\text { costs in order to reduce retail prices) in } \\
\text { rural America vice a large population } \\
\text { center. }\end{array}$ & $\begin{array}{l}\text { (1997) eToys, (1998) Pets.com, and } \\
\text { (1999) Webvan attempt to duplicate } \\
\text { with toys, pet supplies, and groceries } \\
\text { respectively what Amazon.com } \\
\text { (1995) had successfully established } \\
\text { with online book retailing. }\end{array}$ & $\begin{array}{l}\text { (1998) Pets.com receives } \\
\text { venture capital funding from } \\
\text { Amazon.com. }\end{array}$ \\
\hline
\end{tabular}

